\title{
Nitrobenzene oxidizing enzymes in plant cells
}

\author{
T. Varazashvili,* G. Khatisashvili, M. Kurashvili, M. Pruidze, T. Ananiashvili, \\ G. Zaalishvili and M. Gordeziani
}

Durmishidze Institute of Biochemistry and Biotechnology of the Academy of Sciences of Georgia, David Agmasheneblis Kheivani 10 km, 350059 Tbilisi, Georgia

\begin{abstract}
Nitrobenzene NADPH-, $\mathrm{H}_{2} \mathrm{O}_{2}$ - and $\mathrm{O}_{2}$-dependent oxidation in soybean and maize subcellular fractions has been studied. It is demonstrated that in the presence of nicotinamide coenzyme, transformation via monooxygenase has decisive significance. $\mathrm{H}_{2} \mathrm{O}_{2-}$ and $\mathrm{O}_{2}$-dependent transformation of nitrobenzene is accomplished via either enzymatic or non-enzymatic (radical) mechanisms which results in formation of $m$ - and $p$-nitrophenols.
\end{abstract}

Keywords: cytochrome P450, detoxification, monooxygenase, peroxidase, phenoloxidase, xenobiotic

\section{INTRODUCTION}

The initial stage of xenobiotic oxidative degradation is hydroxylation. The principle of the reaction is the following: the lower the molecular polarity, the faster its functionalization [1]. The biochemical goal of this reaction is the increase of the polarity of the organic toxicant, thereby enabling its further effective metabolic utilization. Hydroxylation can be accomplished by the cytochome P450-containing monooxygenases, peroxidases, phenoloxidases etc.

Monooxygenase uses molecular oxygen for xenobiotic oxidation, preliminarily activating it by electrons from nicotinamide coenzymes. In contrast to monooxygenase, peroxidase uses preliminarily activated oxygen atom of hydrogen peroxide or organic hydroperoxides. Besides these hemoproteins, xenobiotic oxidative reactions can also be carried out by copper-containing enzymes, namely the oxygen phenoloxidases. They themselves activate the oxygen consumed for xenobiotic oxidation. It has been observed they can accomplish the reaction via a cooxidation pathway, e.g. phenoloxidase oxidizes the endogenous diphenol and the resultant quinone (or semiquinone) hydroxylates exogenous benzene [2,3] .

From the aforementioned well grounded fact ensues the proposition that in plant cell the functioning of the three mechanisms of xenobiotic oxidation is simultaneous or substitutional.

*Author for correspondence.

Phone: + 99532528279

e-mail: varazashvili@hotmail.com
The goal of the presented investigation was to study nitrobenzene hydroxylation by monooxygenase, peroxidase and phenoloxidase in subcellular fractions and concretely to reveal the enzymatic systems responsible for xenobiotic transformations in particular cell compartments.

\section{MATERIALS AND METHODS}

Selection of oxidation substrate. Nitrobenzene was selected as the substrate of hydroxylation for the following peculiarities:

1. It is chemically stable, autooxidation is not characteristic.

2. Its transformation by oxidative enzymes is achieved only via hydroxylation.

3. The alternative pathway of transformation is reduction of nitro-groups to amino-groups which is achieved only in anaerobic conditions excluded in the current experiments.

4. Its aqueous solubility renders introduction of this substrate into the incubation zone feasible and eliminates the artefacts arising from xenobiotic emulsions or suspensions.

5. The nitrobenzene molecule polarity sharply differs from that of its hydroxy-derivatives, making identification of these products easy.

Research objects. 7-8 day old etiolated soybean and maize root seedlings were used. Seeds were swelled in water (soybean for $1 \mathrm{~h}$, maize for $24 \mathrm{~h}$ ). Plants were moistened with running water daily and maintained at $25-28{ }^{\circ} \mathrm{C}$.

Isolation of subcellular fractions. The following subcellular fractions were isolated from etiolated seedlings by differential centrifugation [4]: rich in plastids (5000 $\mathrm{g}$ residue), rich in mitochondria 
(at $17000 \mathrm{~g}$ in our experiments the intactness of this organelle was not important), microsomes $(105000 \mathrm{~g}$ residue) and cytosol (105000 $g$ residue supernatant). The isolation medium was $0.067 \mathrm{M}$ phosphate buffer, pH 7.4.

Nitrobenzene oxidation. The rate of nitrobenzene oxidation was measured according to the quantity of untransformed nitrobenzene after incubation. Nitrobenzene was incubated with the subcellular fractions: the incubation volume $(7 \mathrm{ml})$ contained $5 \mathrm{mg}$ protein from the subcellular fraction, $0.24 \mathrm{mM}$ nitrobenzene, and $0.165 \mathrm{M}$ phosphate buffer at $\mathrm{pH}$ 7.4. During $30 \mathrm{~min} 1.54 \mathrm{mM}$ NADPH, or $1.13 \mathrm{mM} \mathrm{H}_{2} \mathrm{O}_{2}$, or distilled water previously saturated with oxygen at $4{ }^{\circ} \mathrm{C}$ were added every $5 \mathrm{~min}$. The reaction was stopped by $1 \mathrm{ml} 30 \%$ trichloroacetic acid, which was added before incubation in the controls.

The untransformed nitrobenzene in control and test variants was estimated spectrophotometrically from the difference between the extinction maximum $(310 \mathrm{~nm})$ and minimum $(265 \mathrm{~nm})$. Each sample was measured in comparison with the control not containing nitrobenzene.

For the analysis of inhibition, $1 \mathrm{mM}$ of sodium azide, diethyldithiocarbamate and tiron-a superoxide radical scavenger (4,5-dihydroxy-1,3-benzene disulphonic acid)_-were added to the incubation volume before incubation. For observation of the effect of $\mathrm{CO}$ it was introduced rapidly into the incubation volume $2 \mathrm{~min}$ before the reaction.

Thin layer chromatography. Nitrobenzene hydroxylation products were identified on Kodak silica gel plates in the solvent system benzene: ethanol 95:5. In this system the $R_{\mathrm{f}}$ 's of $m$ - and $p$-nitrophenols equal respectively 0.63 and 0.53 .

The chromatogram was developed by sulphanilic acid disodium salt. The reaction developer contained $0.5 \mathrm{~g}$ diazonium salt per $100 \mathrm{ml} 8 \%$ sodium carbonate solution.

Electronmicroscopic analysis. For the histochemical examination of peroxidase activity in plant cells, some of the 7-day old seedlings were incubated for $24 \mathrm{~h}$ in $0.154 \mathrm{mM}$ nitrobenzene dissolved in water, and some were used as the control. Fixation of the root apex and incubation was carried out by the Geyer method [5]. The material was cut on an LKB III ultramicrotome and observed in a Tesla BS-500 electron microscope.

\section{RESULTS AND DISCUSSION}

Nitrobenzene NADPH-dependent oxidation was studied in subcellular fractions of soybean and maize. For revelation of the catalytic rôle of cytochrome
P450 all subcellular fractions were saturated with carbon monoxide (inhibitor of this hemoprotein). The results obtained are presented in Table 1.

Table 1. Rate of NADPH-dependent nitrobenzene oxidation $\left(\mu \mathrm{mol} \mathrm{min}^{-1}(\mathrm{mg} \text { protein })^{-1}\right)$ in maize and soybean root subcellular fractions, and the effect of $\mathrm{CO}$

\begin{tabular}{|c|c|c|c|c|c|}
\hline Plant & Variant & Plastids & $\begin{array}{l}\text { Mitocho- } \\
\text { ndria }\end{array}$ & $\begin{array}{l}\text { Micro- } \\
\text { somes }\end{array}$ & cytosol \\
\hline \multirow[t]{2}{*}{ Maize } & $\begin{array}{l}\text { Nitrobenzene + } \\
\text { NADPH }\end{array}$ & 0.445 & 0.073 & 0.660 & 0.158 \\
\hline & $\begin{array}{l}\text { Nitrobenzene + } \\
\text { NADPH + CO }\end{array}$ & 0.044 & 0 & 0.063 & 0.016 \\
\hline \multirow[t]{2}{*}{ Soybean } & $\begin{array}{l}\text { Nitrobenzene + } \\
\text { NADPH }\end{array}$ & 0.365 & 0.086 & 1.000 & 0.472 \\
\hline & $\begin{array}{l}\text { Nitrobenzene + } \\
\text { NADPH + CO }\end{array}$ & 0.040 & 0.008 & 0.091 & 0.025 \\
\hline
\end{tabular}

$\mathrm{CO}$ in all cases blocks the assayed NADPHdependent xenobiotic oxidation, corroborating the participation of cytochrome $\mathrm{P} 450$-containing monooxygenase in nitrobenzene oxidative degradation.

Adding hydrogen peroxide intensifies the nitrobenzene oxidation reaction in all plant subcellular fractions. This is especially evident in the cytosolic and microsomal fractions (Table 2). Histochemical

Table 2. Rate of $\mathrm{H}_{2} \mathrm{O}_{2}$-dependent nitrobenzene oxidation $\left(\mu \mathrm{mol} \mathrm{min}^{-1}(\mathrm{mg} \text { protein })^{-1}\right)$ in maize and soybean root subcellular fractions, and effects of azide and tiron.

\begin{tabular}{|c|c|c|c|c|c|}
\hline Plant & Variant & Plastids & $\begin{array}{l}\text { Mitocho- } \\
\text { ndria }\end{array}$ & $\begin{array}{l}\text { Micro- } \\
\text { somes }\end{array}$ & cytosol \\
\hline \multirow{4}{*}{ Maize } & $\begin{array}{l}\text { Nitrobenzene } \\
+\mathrm{H}_{2} \mathrm{O}_{2}\end{array}$ & 0.932 & 0.883 & 1.172 & 1.076 \\
\hline & $\begin{array}{l}\text { Nitrobenzene } \\
+\mathrm{H}_{2} \mathrm{O}_{2}+\text { azide }\end{array}$ & 0.840 & 0.990 & 1.212 & 1.146 \\
\hline & $\begin{array}{l}\text { Nitrobenzene } \\
+\mathrm{H}_{2} \mathrm{O}_{2}+\text { tiron }\end{array}$ & 0.090 & 0.017 & 0.803 & 0.665 \\
\hline & $\begin{array}{l}\text { Nitrobenzene } \\
+\mathrm{H}_{2} \mathrm{O}_{2}+\text { azide } \\
+ \text { tiron }\end{array}$ & 0.007 & 0.012 & 0.012 & 0.032 \\
\hline \multirow{4}{*}{ Soybean } & $\begin{array}{l}\text { Nitrobenzene } \\
+\mathrm{H}_{2} \mathrm{O}_{2}\end{array}$ & 0.864 & 0.753 & 1.225 & 1.099 \\
\hline & $\begin{array}{l}\text { Nitrobenzene } \\
+\mathrm{H}_{2} \mathrm{O}_{2}+\text { azide }\end{array}$ & 0.948 & 0.860 & 1.017 & 1.287 \\
\hline & $\begin{array}{l}\text { Nitrobenzene } \\
+\mathrm{H}_{2} \mathrm{O}_{2}+\text { tiron }\end{array}$ & 0.204 & 0.054 & 0.903 & 0.624 \\
\hline & $\begin{array}{l}\text { Nitrobenzene } \\
+\mathrm{H}_{2} \mathrm{O}_{2}+\text { azide } \\
\text { +tiron }\end{array}$ & 0.022 & 0.017 & 0.088 & 0.003 \\
\hline
\end{tabular}

investigation of maize root apex cells confirms oxidation by the peroxidase mechanism: it was observed that in the control, enzymatic activity is localized in the cell wall, plasmalemma and tonoplast; in microsomes it was not detected at all (fig. 1). After $24 \mathrm{~h}$ nitrobenzene action on roots, enzymatic activity in the afore-listed structures was sharply increased and the most interesting result was 


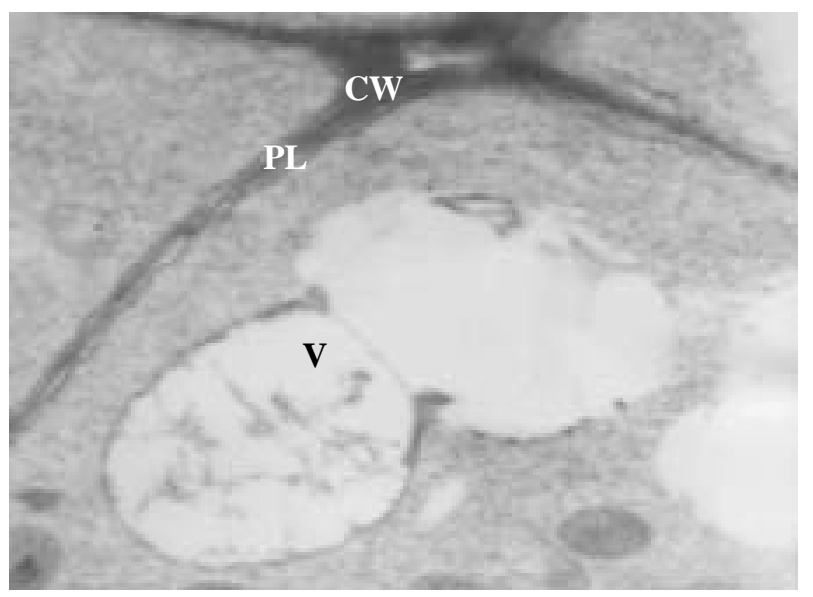

Figure 1. Histochemical reaction products: electron dense precipitates in cell wall (CW), plasmalemma (PL) and tonoplast. Control variant (grown on $\mathrm{H}_{2} \mathrm{O}$ ). $\times 16000$. V: vacuole.

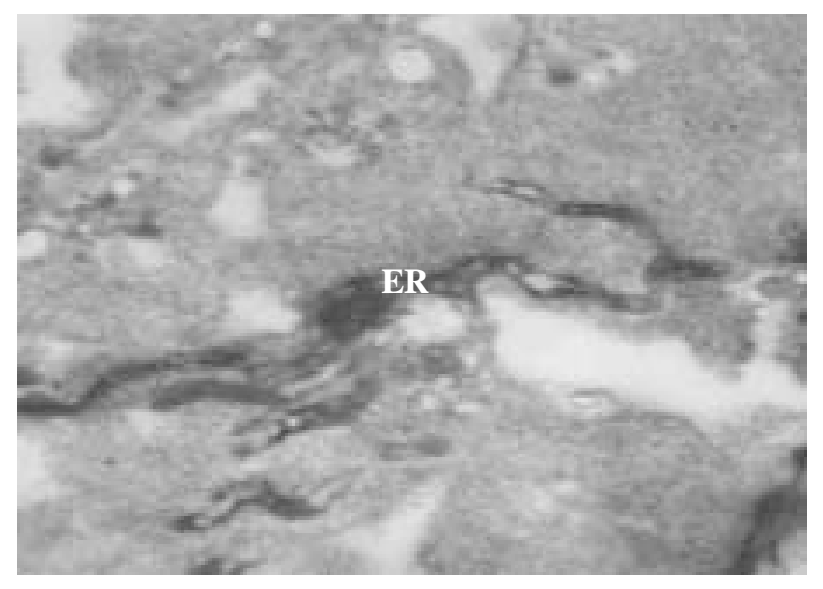

Figure 2. Histochemical reaction products: electron dense precipitates in endoplasmic reticulum (ER). Test (grown on $0.154 \mathrm{mM}$ nitrobenzene solution). $\times 36000$.

the manifestation of high peroxidase activity in the endoplasmic reticulum (fig. 2). This must have resulted not only from induction. It may be supposed that under the action of nitrobenzene, transformation of cytochrome P450 to peroxidase may take place. This was proved in our previous investigations $[6,7]$. Besides, nitrobenzene oxidation is not decreased by adding $\mathrm{NaN}_{3}$, which points to the fact that the peroxidase mechanism is not the only one of oxidation. The participation of free radicals formed from hydrogen peroxide during oxidation could not be excluded. This is corroborated by the significant decrease of nitrobenzene oxidation rate in the presence of tiron (a superoxide radical scavenger) (Table 3). The maximum inhibition of the process occurring during the simultaneous action of $\mathrm{NaN}_{3}$ and tiron points to nitrobenzene oxidation occurring by both peroxidase and radical mechanisms.

The existence of a non-enzymatic (radical) pathway of nitrobenzene transformation is confirmed
Table 3. Rate of $\mathrm{O}_{2}$-dependent nitrobenzene oxidation $\left(\mu \mathrm{mol} \mathrm{min}^{-1}(\mathrm{mg} \text { protein })^{-1}\right)$ in maize and soybean root subcellular fractions, and effects of diethyldithiocarbamate (DDC) and tiron

\begin{tabular}{|c|c|c|c|c|c|}
\hline Plant & Variant & Plastids & $\begin{array}{l}\text { Mitochon- } \\
\text { dria }\end{array}$ & $\begin{array}{l}\text { Micro } \\
\text { somes }\end{array}$ & cytosol \\
\hline \multirow{5}{*}{ Maize } & Nitrobenzene & 0.294 & 0.315 & 0.443 & 0.870 \\
\hline & $\begin{array}{l}\text { Nitrobenzene } \\
+ \text { DDC }\end{array}$ & 0.347 & 0.330 & 0.472 & 0.912 \\
\hline & $\begin{array}{l}\text { Nitrobenzene } \\
+ \text { tiron }\end{array}$ & 0.169 & 0.008 & 0.098 & 0.625 \\
\hline & $\begin{array}{l}\text { Nitrobenzene } \\
+ \text { DDC + tiron }\end{array}$ & 0.007 & 0.003 & 0.025 & 0.012 \\
\hline & Nitrobenzene & 0.462 & 0.415 & 0.622 & 0.961 \\
\hline \multirow[t]{3}{*}{ Soybean } & $\begin{array}{l}\text { Nitrobenzene } \\
+ \text { DDC }\end{array}$ & 0.490 & 0.465 & 0.615 & 0.940 \\
\hline & $\begin{array}{l}\text { Nitrobenzene } \\
+ \text { tiron }\end{array}$ & 0.227 & 0.028 & 0.242 & 0.718 \\
\hline & $\begin{array}{l}\text { Nitrobenzene } \\
+ \text { DDC + tiron }\end{array}$ & 0.049 & 0.007 & 0.085 & 0.009 \\
\hline
\end{tabular}

by identification of the oxidation products: it was observed that in this case $m$-and $p$-nitrophenols were the products.

The action of the nitro-group makes the aromatic $m$-hydrogen atom of nitrobenzene more reactive. Therefore, in this position less energy is needed for hydroxylation than in the $p$-position. Hence, $m$-hydroxylation presumedly proceeds enzymatically and $p$-hydroxylation via active, high energy, forms of oxygen.

Upon addition of diethyldithiocarbamate (phenoloxidase inhibitor) $\mathrm{O}_{2}$-dependent oxidation intensity of nitrobenzene practically did not change; as for tiron, it strongly blocked enzymatic activity in subcellular fractions as well as in the cytosol. Under the simultaneous action of DDC and tiron nitrobenzene oxidation was significantly suppressed in all subcellular fractions. It was observed that when radical processes are blocked by tiron, only nitrobenzene ezymatic oxidation occurs.

Figs 3 and 4 summarize the scheme of nitrobenzene oxidizing enzymes' intracellular distribution on the basis of the obtained results.

\section{CONCLUSIONS}

1.In soybean and maize roots nitrobenzene hydroxylation via monooxygenase procceds most intensively in the microsomal fraction. The reaction is catalyzed by cytochrome $\mathrm{P} 450$ in the presence of NADPH and $m$-nitrophenol is formed as a product.

2.The peroxidase pathway of nitrobenzene oxidation is the most active in microsomes and cytosol. In parallel to the $\mathrm{H}_{2} \mathrm{O}_{2}$-dependent enzymatic oxidation, the non-enzymatic hydroxylation of 
The rate of nitrobenzene oxidation $\mu \mathrm{mol} \mathrm{min}^{-1}(\mathrm{mg} \text { protein })^{-1} \quad$ Maize

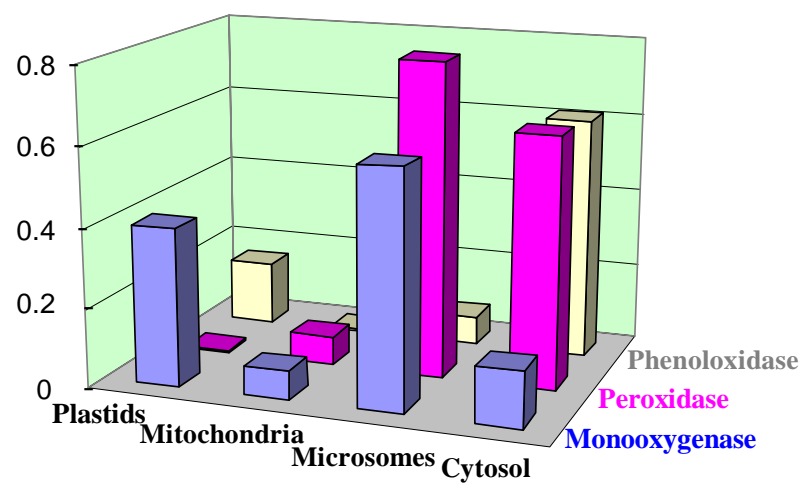

Figure 3. Distribution of nitrobenzene oxidizing enzymes in maize subcellular fractions.

The rate of nitrobenzene oxidation

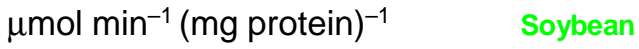

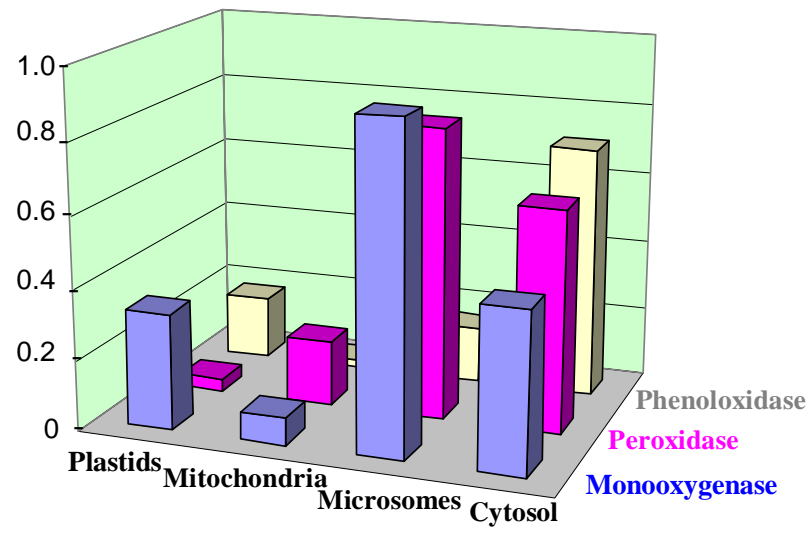

Figure 4. Distribution of nitrobenzene oxidizing enzymes in soybean subcellular fractions.

nitrobenzene by free radicals occurs, resulting in the formation of $p$ - and $m$-nitrophenols.

3.The phenoloxidase pathway of nitrobenzene oxidation is highly effective in the cytosol. $\mathrm{O}_{2}$-dependent nitrobenzene transformation is also accomplished nonenzymatically by free radicals and similarly the reaction products are $m$ - and $p$-nitrophenols.

4.A significant difference regarding the nitrobenzene oxidation mechanisms between the assayed plants was not detected.
It can be supposed that the selection and operation of the oxidation mechanisms are regulated generally by the concentrations of NADPH, $\mathrm{H}_{2} \mathrm{O}_{2}$ and $\mathrm{O}_{2}$.

\section{ACKNOWLEDGMENT}

The work was carried out within the INTASGeorgia 97-0716 project.

\section{REFERENCES}

1. Gogoberidze M., Khatisashvili, G., Ugrekhelidze D., Gordeziani, M., Kvesitadze G. Bioremediation - contemporary strategy of xenobiotics' detoxification. In: ConSoil 2000: Proc. 7th Int. FZK/TNO Conf. on Contaminated Soil, Leipzig, Germany 1 (2000) 397-404.

2. Ugrekhelidze, D., Korte, F., Kvesitadze, G. Uptake and transformation of benzene and toluene by plant leaves. Ecotoxicology Environmental Safety 37 (1998) 24-28.

3. Zaalishvili G.V., Khatisashvili G.A., Ugrekhelidze D.Sh., Gordeziani M.Sh., Kvesitadze G.I. Plant potential for detoxification (Review). Appl. Biochem. Microbiol. 36 (2000) 443-451.

4. Togonidze, L.Sh., Khatisashvili, G.A., Gordeziani, M.Sh., Kobakhidze M.J. NADPHdependent fractional oxidation of dimethylaniline in plant leaves. Bull. Acad. Sci. Georgian SSR 140 (1990) 125-128.

5. Geyer, G. Ultrahistochemie,2nd edn. Jena: Gustav Fischer (1973).

6. Khatisashvili, G., Kurashvili, M., Gordeziani, M., Kvesitadze, G. Monooxygenase and peroxidase pathways of xenobiotics detoxication in higher plants. Fresenius Environmental Bull.2 (1993) 103-108.

7. Khatisashvili, G., Gordeziani, M., Kvesitadze, G., Korte, F. Plant monooxygenases: participation in xenobiotic oxidation. Ecotoxicology Environmental Safety 36 (1997) 118-122. 